\title{
SUPERNATURALISM AND MYSTICISM IN WILLIAM SHAKESPEARE'S PLAY HAMLET
}

\section{Muharrani Nurmalasari}

Islamic University of North Sumatera

nurmalasarimubarrani@yahoo.co.id

\author{
Ruly Adha \\ IAIN Langsa \\ adharuly@yahoo.com
}

\begin{abstract}
William Shakespeare is the greatest dramatist in the world. He has produced a lot of literary works especially play or drama. Some of his plays still exist until now such as Julius Caesar, Hamlet, The Merchant of Venice, etc. Even, one of his plays Romeo and Juliet has been translated into several languages in the world. He produces two types of plays, namely comedy which usually talks about love and tragedy which talks about sadness. In tragedy plays, Shakespeare always puts supernatural and mystical elements such as in Julius Caesar, Macbeth, Hamlet, etc. The supernatural and mysticism elements are usually marked by the appearance of apparition, witch, fairy, etc, and the elements can determine the fate of main characters. This article tries to describe how Shakespeare puts supernatural and mystical elements in one of his tragedy plays Hamlet.
\end{abstract}

\section{Keyword}

Supernatural, mysticism, play and tragedy

\section{INTRODUCTION}

Supernatural and mystic cannot be measured by logical thinking. Literally, supernatural means something related to magical which cannot be explained by science. Meanwhile, mystic or mystical is related to spiritual power. Supernatural and mystic are the prominent feature of Shakespeare's plays. As a romantic artist, Shakespeare feels the presence of unseen powers in nature. These unseen powers are more real than the world. The supernatural has a special charm for romantic artists, especially Shakespeare. 
They are attracted by the stories of fairies, ghosts, and witchcraft. Their literary works are an expression of their wonder at the magic and mystery of the universe (Varshney, 1990).

\section{A Short Biography of William Shakespeare}

William Shakespeare was born on April $23^{\text {rd }}, 1564$ in the village of Stratford-on-Avon in the country of Warwickshire. His father John Shakespeare was a farmer's son who came to Stratford about 1531, and began to prosper as a trader in corn, wheat, leather, and agricultural products. His mother Mary Arden was the daughter of a prosperous farmer, descended from an old family of mixed Anglo-Saxon and Norman blood. It is generally believed that neither the poet's mother nor his father could read or write. He attended the Grammar School at Stratford where he picked up 'small Latin and less Greek'. When Shakespeare had attained the age of 14, his father lost his little property and fell into debt. He left school to help to support the family of younger children. In 1582, Shakespeare married Anne Hathaway, the daughter of a peasant family. She was eight years older than Shakespeare. His first child, Susanna, was baptized in May 1583, to be followed in February 1585 by twins, Hamnet and Judith (Lall, 1990).

Shakespeare had written many literary works especially plays. Some of them were very famous. Shakespeare's works have been divided into four periods corresponding to the growth and experience of his life and mind (Lall, 1990). The periods are as follows:

\subsection{Period of Early Experimentation (1588-1593)}

The works of this period are: Titus Andronicus, Henry VI (three parts), Love's Labour's Lost, Comedy of Errors, Two Gentlemen of Verona, Richard III, 
Richard II, Romeo and Juliet. In this period, he also writes two poems, Venus and Adonis and The Rape of Lucrece. The work of this period extremely slight in texture; the treatment of life is superficial; there is no depth of thought or characterization; and the art is evidently immature. The work is characterized by youthful exuberance of imagination, by extravagance of language, and by a constant use of puns, conceits, and other affectations.

\subsection{Period of the Great Comedies and Chronicle Plays (1594-1600)}

The works of this period are: King John, The Merchant of Venice, Henry IV (part I and part II), Henry $V$, The Taming of the Shrew, The Merry Wives of Windsor, Much Ado About Nothing, As You Like It, and Twelfth Night. These plays show a rapid growth and development in the poet's genius. They reflect a deeper knowledge of human life and human nature; the characterization and the humour have become more penetrating; thought has become more weighty; rime has largely been abandoned for prose and blank verse, and the blank verse itself has lost its stiffness.

\subsection{Period of the Great Tragedies, and of the Sombre or Bitter Comedies (1601-1607)}

The works of this period are: Julius Caesar, Hamlet, All's Well That Ends Well, Measure for Measure, Troilus and Cressida, Othello, King Lear, Macbeth, Antony and Cleopatra, Coriolanus, and Timon of Athens. This is a period of gloom and depression and it marks the full maturity of his powers. His dramatic power, his intellectual power, and his power of expression are at their highest. This is the time of his supreme masterpieces. His attention is, however, occupied exclusively with the darker side of human experience. The sins and 
weaknesses of man from the theme of his plays; the emphasis is thrown on evil and the tone is either grave or fierce.

\subsection{Period of the Later Comedies or Dramatic Romances (1608-1612)}

The plays of this period are: Pericles, Cymbeline, The Winter's Tale, The Tempest, and the unfinished Henry VIII. During this period, the temper of Shakespeare has changed from bitter and gloomy to serene and peaceful. The heavy clouds have melted away from the sky. A tender and gracious tone prevails. The groundwork is still furnished by tragic passion, but the evil is no longer permitted to have its way. The evil is controlled and conquered by the good. At the same time, they show the decline of Shakespeare's dramatic powers. They are often careless in construction and unsatisfactory in characterization, while there is a decline in style and versification also.

From the periods above, it can be inferred that William Shakespeare has produced two types of plays, comedy and tragedy. If the play ends with happy ending, it is called comedy. Meanwhile, if the play ends with sad ending, it is called tragedy. Shakespeare's comedy usually has a theme of love. However, in tragedy, Shakespeare puts supernatural elements and it always ends with sadness or death. The appearance of supernatural elements always brings negative effect to the main character, for example, in Julius Caesar, Macbeth, Hamlet, etc. In other word, the appearance of supernatural elements makes the main character's life ruined.

\section{A Brief Summary of Hamlet}

Hamlet, the young Prince of Denmark, was once the gayest and most lively of men, taking part in all kinds of hunting and sports; but a great trouble came to cloud his life. His father died suddenly in a mysterious way. 
Hamlet was told that the old king had died from the bite of a snake while he was asleep one afternoon in his orchard. Soon after his death, Claudius, the brother of the dead king, and uncle to Hamlet, married the queen, and now he was the reigning king. Hamlet did not like his mother to marry again so quickly. Hamlet did not love his uncle. A suspicion had crept into Hamlet's mind that Claudius had brought about the death of his father in order to get the crown for himself, and that his mother had known of it; and this last thought drove Hamlet almost mad. The new king and the queen noticed that the prince was gloomy and unhappy, but they did not think that Hamlet suspected them of a foul crime, so they did their best to cheer him up.

Then, a strange story was told to Hamlet. For three nights in succession the guard of soldiers that kept watch by night before the castle had seen a ghost. Hamlet's best friend, Horatio, had also seen it and brought the news to the prince. The ghost had appeared at midnight. It was dressed from head to foot in armour which was just like the armour of the old dead king, and its face was just like his face. Hamlet questioned the soldiers and from their answers he felt sure that the story was true, so he determined to sit up the next night and watch for the ghost himself. For if the ghost was indeed that of his father, it surely wanted to tell him something, and it would be able to explain some of the doubts and fears that were in his mind.

The next night, Hamlet, Horatio, and one of the soldiers watch in front of the castle. Suddenly, the ghost had come again. Hamlet exclaimed in wonder: 'What does your coming mean? You, so like my father? Are you really he, or another? What would you have us do?' In answer the spirit beckoned to Hamlet to go aside with it away from his two companions. Hamlet followed the ghost and the ghost quickly told him that in truth he had been murdered. The ghost said, "Now, it was given out that sleeping in 
my orchard, a serpent stung me; but know, thou noble youth, the serpent that did sting thy father's life now wears his crown". The ghost commanded Hamlet to revenge his foul and most unnatural murder, but he was not to kill his mother, who had shared in the crime. She was to be left to suffer the punishment of sorrow and remorse for her own misdeeds. So, bidding his son not to forget his command, the old king's spirit vanished.

So in accordance with his plan, Hamlet's talk and behaviour became stranger than ever, especially when he was with the king and queen. His uncle and the queen were more and more puzzled. Hamlet tried to find out the way to prove that the king and queen were guilty. Hamlet made a play called 'The Murder of Gonzago', in which a duke named Gonzago was poisoned in his garden by a near relative who afterwards married his widow. Hamlet made some changes in the play, in order that it might be as like the actual murder of his father as possible. After seeing the play, Claudius was panic-stricken. The queen called Hamlet to her room. The queen had made the cunning old courtier Polonius hide behind the curtains in her room so that there should be a witness to anything that Hamlet said. When Hamlet entered the room, the queen began to approach him for his conduct. Hamlet tried to make her mother confess her guilty. The queen refused it and shouted, "Help! Help!" Polonius, hidden behind the curtains, thought Hamlet meant to kill his mother. Polonius was very frightened and also asked for help. Hamlet thought that it was the king. Hamlet ran his sword through the curtains and killed Polonius on the spot. Hamlet was very surprised to see that it was not the king.

The king planned to get rid of Hamlet for the king realized that Hamlet was dangerous. The king planned to send Hamlet out of the country. The king pretended to Hamlet that he was sending him there on affairs of state, 
for at this time England belonged to Denmark. In reality, the king sent a sealed letter, carried by two courtiers who went with the prince, to the King of England ordering him to put Hamlet to death as soon as he landed on English soil. Hamlet pretended to be willing to carry out the royal command. Hamlet found and opened the sealed packet containing the letter from Claudius to the King of England. Then, he rubbed out his own name from the letter and in its place he put the names of the two officers who were with him. Hamlet escaped the king's plot and he sailed at the nearest port in Denmark. As soon as he landed he wrote a letter to his uncle telling him that he was in Denmark again. Hamlet told Horatio his adventures.

The king was still determined to get rid of Hamlet. The king decided to make use of Laertes' anger against the slayer of his father Polonius, and knowing that they were both skilful fencers he arranged for a match to take place between them. The king persuaded Laertes to use a sharp pointed sword which was forbidden in matches and to put poison on it, so that even a scratch would prove fatal. Then a challenge was sent to Hamlet who thinking that Laertes wanted a friendly match accepted the challenge as a sign of good will. The king also placed two bowls of wine on a table near him at the place where the fencing match was to take place, and in one of these bowls he put a deadly poison, planning that he would drink to Hamlet's success between the bouts and pass him the poisoned bowl to answer the toast.

At first the fight went rather in the prince's favour, and when they stooped to rest the king drank to his success, but Hamlet would not drink until he had finished another bout. The king was so eagerly watching for the fatal thrust that he took no notice of the queen who was sitting beside him. She, being thirsty, took up a bowl of wine to drink, and the king did not see 
that she was drinking from the poisoned bowl. At that moment Laertes pierced Hamlet's skin with a sudden thrust. Hamlet lost his temper when he knew that Laertes was using a sharp-pointed foil. In the struggle, he seized Laertes' weapon and wounded him with the foil which Laertes himself had poisoned. The king cried out to separate them. At the same time the queen was seen suddenly to fall, crying out that she had been poisoned and she died immediately.

Hamlet, seeing treachery all around him, ordered the attendants to shut the doors that no one should escape. Laertes fell to the ground, poisoned by the wound Hamlet had given him. Then, the prince saw the king's foul plot to kill him. Hamlet turned on the king and stabbing him with the poisoned weapon, killed him instantly. His tragic destiny fulfilled, Hamlet called his faithful friend Horatio to his side, and begged him to make known the true story of his father's murder and of its revenge. Horatio had made a move as if to drink the poisoned wine and so accompany his friend in death, but when Hamlet begged him, he promised to live on and tell to the world the full story of the tragedy. This was the end of the brave and noble Prince of Denmark. He was mourned as one who would have made a splendid king, and he was carried to his burial with soldiers' music, and a people's mourning.

\section{Supernaturalism and Mysticism in Hamlet}

Aspects of supernaturalism and mysticism are seen in the opening of the play. It is marked by the appearance of the ghost of Hamlet's father, the late King Denmark. The ghost has been seen twice by two guards of the castle, Marcellus and Bernardo. They decide to bring Horatio to the spot where the ghost appears. Horatio does not believe of what they said. He is skeptical 
about the existence of ghosts. However, Horatio still comes to the place where the ghost appears in order to verify the report of the appearance of the ghost given by Marcellus and Bernardo.

Mar. Holla, Barnardo!

Bar. Say, what, is Horatio there?

Hor. A piece of him.

Bar. Welcome, Horatio. Welcome, good Marcellus.

Hor. What, has this thing appear'd again tonight?

Bar. I have seen nothing.

Mar. Horatio says 'tis but our fantasy,

And will not let belief take hold of him,

Touching this dreaded sight twice seen of us.

Therefore I have entreated him along

With us to watch the minutes of this night,

That if again this apparition come,

He may approve our eyes and speak to it.

Hor. Tush, tush 'twill not appear.

Bar. Sit down awhile,

And let us once again assail your ears,

That are so fortified against our story,

What we have two nights seen.

Hor. Well, sit we down.

And let us hear Barnardo speak of this.

Bar. Last night of all,

When yond same star that's westward from the pole,

Had made his course t'illume that part of heaven

Where now it burns, Marcellus and myself, 
The bell then beating one - (I. i. 20-42)

Finally, the ghost appears. Horatio is trembling and looks pale with fear because the ghost resembles Hamlet's father, the late of King Denmark. Now, he believes in what his friends said before. Horatio tries to speak with the apparition but it just walks away.

Mar. Peace, break thee off. Look where it comes again.

Bar. In the same figure like the King that's dead.

Mar. Thou art a scholar, speak to it, Horatio.

Bar. Looks a not like the King? Mark it, Horatio.

Hor. Most like. It harrows me with fear and wonder.

Bar. It would be spoke to.

Mar. Question it, Horatio.

Hor. What art thou that usurp'st this time of night,

Together with that fair and warlike form

In which the majesty of buried Denmark

Did sometimes march? By heaven, I charge thee speak

Mar. It is offended.

Bar. See, it stalks away.

Hor. Stay, speak, speak, I charge thee speak.

Mar. 'Tis gone and will not answer.

Bar. How now, Horatio? You tremble and look pale.

Is not this something more than fantasy?

What think you on't?

Hor. Before my God, I might not this believe

Without the sensible and true avouch

Of mine own eyes. (I. i. 43-61) 
After a few moments, the apparition comes again. Horatio tries very hard to speak with it. The ghost seems that it wants to say something. However, when the ghost hears the cock crows, it disappears again.

Hor. But soft, behold. Lo, where it comes again.

I'll cross it though it blast me. (Ghost spreads its arms)

Stay, illusion:

If thou hast any sound or use of voice,

Speak to me.

If there be any good thing to be done

That may to thee do ease, and grace to me,

Speak to me;

If thou art privy to thy country's fate,

Which, happily, foreknowing may avoid,

O speak;

Or if thou hast uphoarded in the life

Extorted treasure in the womb of earth,

For which they say your spirits oft walk in death,

Speak of it, stay and speak. (The cock crows)

Stop it, Marcellus.

Mar. Shall I strike at it with my partisan?

Hor. Do if it will not stand.

Bar. 'Tis here.

Hor. 'Tis here.

Mar. 'Tis gone.

We do it wrong, being so majestical,

To offer it the show of violence,

For it is as the air, invulnerable, 
And our vain blows malicious mockery.

Bar. It was about to speak when the cock crew (I. i. 129-152)

Horatio is Hamlet's best friend. Horatio tells all his experiences in the previous nights. Hamlet is eager to see the ghost. Therefore, Horatio invites Hamlet to the place where the ghost always appears. Being accompanied by Horatio and Marcellus, Hamlet goes to the place and the ghost appears again. However, the ghost gives a sign to Hamlet to follow him. It seems that the ghost wants to tell something only to Hamlet. The ghost orders Hamlet to follow him in a place alone without being accompanied by his guards.

Hor. Look, my lord, it comes.

Ham. Angels and ministers of grace defend us!

Be thou a spirit of health or goblin damn'd,

Bring with thee airs from heaven or blasts from hell,

Be thy intents wicked or charitable,

Thou com'st in such a questionable shape

That I will speak to thee. I'll call thee Hamlet.

King, father, royal Dane. O answer me.

Hor. It beckons you to go away with it,

As if it some impartment did desire

To you alone.

Mar. Look with what courteous action

It waves you to a more removed ground.

But do not go with it.

Hor. No, by no means.

Ham. It will not speak. Then I will follow it. 
Hor. Do not, my lord.

Ham. It waves me still.

Go on, I'll follow thee. (I. iv. 38-78)

At last, the ghost reveals to Hamlet who he is. The ghost says that he is his father. The ghost says that Hamlet must take a revenge of his death. Hamlet is very surprised to hear that his father was murdered.

Ghost. Mark me.

Ham. I will.

Ham. Speak, I am bound to hear.

Ghost. So art thou to revenge when thou shalt hear.

Ham. What?

Ghost. I am thy father's spirit,

Doom'd for a certain term to walk the night,

And for the day confin'd to fast in fires,

Till the foul crimes done in my days of nature

Are burnt and purg'd away. But that I am forbid

To tell the secrets of my prison-house,

I could a tale unfold whose lightest word

Would harrow up thy soul, freeze thy young blood,

Make thy two eyes like stars start from their spheres,

Thy knotted and combined locks to part,

And each particular hair to stand an end

Like quills upon the fretful porpentine.

But this eternal blazon must not be

To ears of flesh and blood. List, list, O list! 
If thou didst ever thy dear father love -

Ham. O God!

Ghost. Revenge his foul and most unnatural murder.

Ham. Murder!

Ghost. Murder most foul, as in the best it is

But this most foul, strange and unnatural.

Ham. Haste me to know't, that I with wings as swift

As meditation or the thoughts of love

May sweep to my revenge. (I. v. 1-30)

The ghost reveals to Hamlet how he died. The ghost says that he was murdered by Claudius, Hamlet's uncle. Hamlet is shocked. After murdering Hamlet's father, Claudius married Hamlet's mother. Claudius is a very ambitious person. He wants to get Hamlet's father throne.

Ghost. I find thee apt.

And duller shouldst thou be than the fat weed

That roots itself in ease on Lethe wharf,

Wouldst thou not stir in this. Now, Hamlet, hear.

'Tis given out that, sleeping in my orchard

A serpent stung me - so the whole ear of Denmark

Is by a forged process of my death

Rankly abus'd - but know, thou noble youth,

The serpent that did sting thy father's life

Now wears his crown.

Ham. O my prophetic soul! My uncle!

Ghost. Ay, that incestuous, that adulterate beast,

With witchcraft of his wit, with traitorous gifts -

$\mathrm{O}$ wicked wit, and gifts that have the power 
So to seduce! - won to his shameful lust

The will of my most seeming - virtuous queen.

O Hamlet, what a falling off was there,

From me, whose love was of that dignity

That it went hand in hand even with the vow

I made to her in marriage, and to decline

Upon a wretch whose natural gifts were poor

To those of mine.

But virtue, as it never will be mov'd,

Though lewdness court it in a shape of heaven,

So lust, though to a radiant angel link'd,

Will state itself in a celestial bed

And prey on garbage.

But soft, methinks I scent the morning air:

Brief let me be. Sleeping within my orchard,

My custom always of the afternoon,

Upon my secure hour thy uncle stole

With juice of cursed hebenon in a vial,

And in the porches of my ears did pour

The leperous distilment, whose effect

Holds such an enmity with blood of man

That swift as quicksilver it courses through

The natural gates and alleys of the body,

And with a sudden vigour it doth posset

And curd, like eager droppings into milk,

The thin and wholesome blood. So did it mine,

And a most instant tetter bark'd about, 
Most lazar-like, with vile and loathsome crust

All my smooth body.

Thus was I, sleeping, by a brother's hand

Of life, of crown, of queen at once dispatch'd,

Cut off even in the blossoms of my sin,

Unhousel'd, disappointed, unanel'd,

No reck'ning made, but sent to my account

With all my imperfections on my head.

O horrible! O horrible! Most horrible!

If thou has nature in thee, bear it not,

Let not the royal bed of Denmark be

A couch for luxury and damned incest.

But howsomever thou pursuest this act,

Taint not thy mind nor let thy soul contrive

Against thy mother aught. Leave her to heaven,

And to those thorns that in her bosom lodge

To prick and sting her. Fare thee well at once:

The glow - worm shows the matin to be near

And gins to pale his uneffectual fire.

Adieu, adieu, adieu. Remember me. (I. v. 31-91)

\section{THE EFFECT OF SUPERNATURALISM AND MYSTICISM IN}

\section{HAMLET}

The appearance of the ghost of Hamlet's father really gives the effect to the main character, Hamlet. The ghost appears many times to Hamlet. It has to appear because the ghost must reveal an important secret. The ghost tells the way how his father died, and the man who must take the responsible 
of his father's death is Hamlet's uncle, Claudius. Claudius is very ambitious person. He wants to be a King of Denmark. He plans to kill Hamlet's father by poisoning him. After poisoning Hamlet's father, Claudius married with Hamlet's mother. The ghost, then, orders Hamlet to kill his uncle, Claudius.

After receiving the order from the ghost, Hamlet becomes a strange person. He does not care with his own life, even with his love, Ophelia, until Ophelia died. After Ophelia died, Hamlet became very sad. He thinks that his life does not have a meaning anymore; however, he must do what the ghost said. Finally, Hamlet can reach his goal. He kills his uncle, Claudius. However, at the same time, Hamlet also died. From the play, it can be seen that Hamlet never feels happy in his life. It is caused by the ghost. The appearance of the ghost has changed Hamlet's life. This is the reason why this play is categorized as a tragedy.

As a comparison, the effect of supernaturalism and mysticism also can be seen in others Shakespeare's tragedies, such as Macbeth and Julius Caesar. In Macbeth, some witches have made Macbeth become a cruel person. The witches said to Macbeth that someday he will become a king of Scotland. This prophecy has a great influence for Macbeth. When he comes home, Macbeth tells the prophecy to his wife. Macbeth's wife has a bad character and she is an ambitious woman. So, when hearing the prophecy, Macbeth's wife orders him to kill the king so that the prophecy becomes real. Finally, Macbeth kills the king. However, he has not become a king yet. He becomes cruel. He kills everyone who opposes to him. At the end of the play, Macbeth is beheaded. Macbeth died because of his ambition that comes from the prophecy of the witches. In Julius Caesar, supernatural and mysticism also give an effect. Julius Caesar was murdered by his own friend, Brutus. The 
ghost of Caesar appears to make a revenge for his death. At the end of the play, Brutus who had stabbed Caesar also died.

From the description above, the supernatural and mystical elements in some Shakespeare's tragedies play an important role. The appearance of apparition or witch gives a great contribution to the destiny of the main characters. The life of main characters is ruined because of following the command of the ghost or because of the prophecy of witches. We can infer that supernatural or mystical elements bring sadness or death to the main characters. On the other hand, supernatural or mystical elements always bring negative effects to the main characters.

\section{CONCLUSION}

William Shakespeare is the greatest dramatist in the world who has produced a lot of literary works especially play or drama. He produces two types of plays, namely comedy which usually talks about love and tragedy which talks about sadness. In tragedy plays, Shakespeare always puts supernatural and mystical elements such as in Hamlet. The supernatural and mysticism elements are usually marked by the appearance of apparition, witch, fairy, etc. In Hamlet, the supernatural and mystical elements are the appearance of the ghost of Hamlet's father. Hamlet's father was killed by his brother, Claudius, because his brother wanted to be a King of Denmark. After poisoning Hamlet's father, he married with Hamlet's mother. The appearance of the ghost of Hamlet's father was aimed to command Hamlet to revenge his soul and his unnatural murder. The ghost appeared many times to Hamlet to reveal the conspiracy of Hamlet's uncle and also commanded Hamlet to kill his uncle. Finally, Hamlet succeeded in killing his uncle although Hamlet himself also died. The appearance of supernatural 
elements always brings negative effects to the main characters such as sadness or death. On the other hand, the appearance of supernatural and mystical elements makes the main character's life ruined.

\section{REFERENCE}

Lall, Ramji. (1990). William Shakespeare's Hamlet. New Delhi: Rama Brothers.

Lamb, Charles \& Lamb, Marry Anne. (1980). Tales from Shakespeare. London: Oxford University Press.

Prasad, B. (1965). A Background of English Literature. New Delhi: Macmillan.

Sinha, Manindranath. (1999). A Handbook of the Study of Literature. Bareilly: Prakash Book Depot.

Tilak, Raghukul. (1991). A Short History of English Literature. Bareilly: Prakash Book Depot.

Varshney. (1990). Literary Ages and Movement. Bareilly: Student Store.

Wyatt, H.G. (1957). Stories from Shakespeare. Hong Kong: Oxford University Press. 